\title{
The Preliminary Inquiry in Ethiopia and Its Adverse Impact on the Rights of the Accused
}

DOI http://dx.doi.org/10.4314/mlr.v14i1.6

\section{Abstract}

Wondwossen Demissie Kassa *

Whether preliminary inquiry should be conducted following completion of criminal investigation was one of the issues that arose in criminal proceedings of leaders of some opposition parties who were arrested (in June and July 2020) following the assassination of Hachalu Hundessa. The Court accepted the request of the Office of the Attorney General for the holding of preliminary inquiry. While the request of the Office of the Attorney General and the ruling of the court are consistent with the 1961 Criminal Procedure Code, in view of the unique nature of the Ethiopian Preliminary Inquiry, both the request and the ruling adversely affect the right of the accused to a fair trial. The application of the law regulating preliminary inquiry would be a departure from the principle of equality of arms and the right of the accused to confrontation, both of which are elements of the right to a fair trial. It is argued (in this comment) that using evidence obtained during preliminary inquiry against the accused is inconsistent with the FDRE Constitution and relevant international legal instruments.

\section{Key terms}

Preliminary inquiry $\cdot$ Equality of arms $\cdot$ The right to confrontation · Fair trial Office of the Attorney General

\section{Citation:}

Wondwossen Demissie Kassa (2020), 'The Preliminary Inquiry in Ethiopia and Its Adverse Impact on the Rights of the Accused', 14 Mizan Law Review 1: 150-160.

\footnotetext{
* Wondwossen Demissie Kassa (PhD), Asst. Professor, Addis Ababa University School of Law Email: wondwossend@yahoo.com ORCID: 0000-0002-0494-6835
} 


\section{Introduction}

Following Hachalu Hundessa's assassination and the resulting violence in Oromia and Addis Ababa, there have been detention, ${ }^{1}$ investigation, preliminary inquiry and trials including leaders of several political parties. Whether Preliminary Inquiry (PI) should be conducted following completion of their investigation was one of the controversial issues ${ }^{2}$ between the Office of the Attorney General (OAG) and leaders of different opposition parties (the accused). ${ }^{3}$

Citing its discretion to make use of the procedure under the 1961 Criminal Procedure Code of Ethiopia (Cr. Pro. C.), the OAG argued for the holding of PI, despite the objection from the accused. ${ }^{4}$ The Court overruled the objection and decided that PI be conducted as per the OAG's request. ${ }^{5}$ The OAG called its witnesses. Some testified with their identity concealed and others in a closed court. ${ }^{6}$

While this comment is prompted by this case, its scope goes beyond this specific case and relate to the law regulating PI in general. Accordingly, it examines the law of PI under the Cr. Pro. C. in the light of the rights of the

\footnotetext{
Acronyms

ICCPR the International Covenant on Civil and Political Rights

OAG Office of the Attorney General

PI Preliminary Inquiry
}

Abbreviation: Cr. Pro. C (Criminal Procedure Code

${ }^{1}$ Aljazeera news (2020), more than 9,000 arrests in Ethiopia since June killing of singer. 14 August. https://www.aljazeera.com/news/2020/08/9000-arrests-ethiopia-junekilling-singer-200813135002131.html ; Human Rights Watch (2020), Ethiopia: Opposition Figures Held Without Charge: Police Deny Lawyers, Relatives Access; Ignore Bail Orders. 15 August.

${ }^{2}$ In view of that Article 38 of the Cr. Pro. C. provides a list of alternatives for the prosecution and empowers the prosecution to make a choice from the list based on completed police investigation file, it is unclear how the issue of conducting preliminary inquiry would arise before court of law.

3 Leul Estifanos (2020), Amid defence objections, Ethiopian court grants pre-trial inquiry for Jawar et al, Ethiopia Insight, August 15, 2020. <https://www.ethiopiainsight.com/2020/08/15/amid-defence-objections-ethiopian-court-grants-pre-trial-

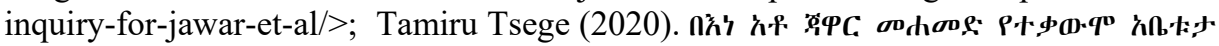

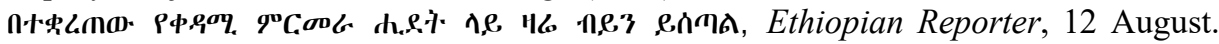
$<$ https://www.ethiopianreporter.com/article/19553>

${ }^{4}$ Leul (2020), supra note 3.

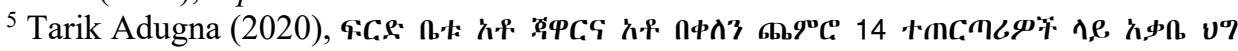

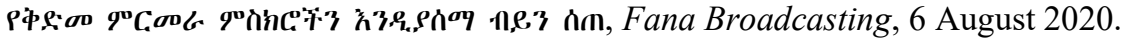

${ }^{6}$ Ibid. 
accused and concludes that the law departs from principle of equality of arms and contravenes the right of the accused to confrontation, both of which are constituent elements of the right to a fair trial. It is proposed that concerns raised in this comment be addressed in the Draft Criminal Procedure Code. In relation to the case at hand, the trial court has to evaluate the admissibility of depositions given during PI in the light of its impact on the right of the accused and consider excluding it from being used as evidence against the accused.

\section{The Procedure of PI in Brief: Uniqueness of Ethiopia's PI and Its Absurd Consequences}

PI constitutes a post-investigation but pre-trial proceeding where the prosecution would be given an opportunity to call its witnesses to be heard and recorded before court of law. Where PI is to be conducted, it shall be held before a First Instance Court (committal court) within whose area of jurisdiction the offence was committed and by the prosecutor acting before this court. ${ }^{7}$

After witnesses of the prosecution have been heard and their testimony recorded, the accused would be given an opportunity to make a statement in response to the prosecution's charge. If they opt to make one, it shall be recorded, read over to and signed by them to form part of the PI file. ${ }^{8}$ The court is empowered to call any person, whose testimony it thinks is needed in the interest of justice, to testify before it. ${ }^{9}$ Then, the court would commit the accused for trial before the High Court. ${ }^{10}$ The proceeding would be concluded by the court 'requiring' the accused to provide list of witnesses they wish to call during their trial. ${ }^{11}$

In modern times, it is a common requirement that before a criminal charge is filed for trial the prosecution's case relating to criminal cases of major importance be evaluated. ${ }^{12}$ Different jurisdictions use different names

${ }^{7}$ Cr. Pro. C., Articles $81 \& 83$ (3)

${ }^{8}$ Id., Articles 85 \& 86.

${ }^{9}$ Id., Article 87.

${ }^{10}$ Id., Article 89 (1).

${ }^{11} I d$., Article 89 (3). It is unclear if the accused, during their trial, would be precluded from calling witnesses whose name they did not provide at this stage.

12 Gary L. Anderson (1970), The Preliminary Hearing - Better Alternatives or More of the Same, 35 MO. L. REV. 281. 
- "Preparatory Examination," 13 "Preliminary Hearing"14 or "Examining Trials" ${ }^{15}$ - to refer to what the Cr. Pro. C. calls Preliminary Inquiry. While, as noted above, the PI forms part of the criminal process under the Criminal Procedure Code, it is different from how it is incorporated in other jurisdictions in two respects - (i) its purpose and (ii) the role of the prosecution in deciding whether PI should be held.

\subsection{Purpose}

Both in continental and common law legal traditions, the primary purpose of PI is to determine whether a crime has been committed and whether there is a prima facie case to believe the accused is guilty thereof and to hold him over for trial. ${ }^{16}$ Essentially, it is a procedure intended to protect the interest of the accused. It serves to weed out groundless or unsupported charges and to relieve the accused of degradation and the expense of a criminal trial. Thus, the court before which PI is conducted is empowered to dismiss the prosecution's case if there is no prima facie evidence to warrant trial of the accused. Only incidentally does PI serve prosecution's interest such as by preserving their evidence.

Ethiopian law is different. As noted above, the committal court simply lets witnesses of the prosecution testify, records their testimony and automatically commits the accused for trial. It does not have the power to weigh evidence and dismiss the prosecution's case no matter how weak it might be. From Article 144 of the Cr. Pro. C., which authorizes depositions taken in PI to be put in evidence under some circumstances, it is clear that the main purpose of PI under Ethiopian law, unlike in other jurisdictions, is preserving evidence of the prosecution. Indeed, the OAG invokes this purpose in support of its argument for the holding of $\mathrm{PI}^{17}$ By not recognizing its primary function, the law has made the PI, a procedure which

13 P.J. Schwikkard and S.E. van der Merwe, "South Africa," in Craig M. Bradley, Criminal Procedure: A Worldwide Study (Durham, North Carolina: Carolina Academic Press, 1999) at 347.

${ }^{14}$ Eliahu Harnon and Alex Stein, "Israel," in Bradley (1999), supra note 12, at 237; Rachel Van Cleave, "Italy," in ibid., at 270; Catherine Newcombe, "Russian Federation," in ibid., at 303.

15 United States, in Russell L. Weaver, et al., Principles of Criminal Procedure (St. Paul, Mennosota: West Group, 2004) at 276.

${ }^{16}$ United States, Id., at 277; Russia, Catherine Newcombe, "Russian Federation," in Bradley (1999), supra note 12, at 303; Italy, Rachel Van Cleave, "Italy," in ibid., at 270-71; Deborah Day Emerson (1984), The Role of the Grand Jury and the Preliminary Hearing in Pretrial Screening.

${ }^{17}$ Tamiru (2020), supra note 3; Leul (2020), supra note 3. 
is normally meant to protect the accused from unwarranted prosecution, to exclusively benefit the prosecution. ${ }^{18}$

The primary purpose of PI is omitted not because the then law makers did not want the PI to serve this purpose. As Fisher noted, it is because at the time the committal court, the then Woreda Courts, were not staffed with lawyers who were qualified enough to evaluate and decide on whether or not the High Court Prosecutor has a prima facie case to warrant trial. ${ }^{19}$

This situation has been changed. While judges at First Instance Courts are capable of discharging the responsibilities that the primary purpose of PI entails, the law has not been amended to reflect this reality. Instead, there has been a practice to disregard the PI to an extent the law is described as having been repealed by disuse. ${ }^{20}$

\subsection{Prosecutor's power}

Article 38 of the Cr. Pro. C. provides for the list of alternatives available to the prosecution once police investigation is completed. One of the options is to order that PI be conducted in accordance to Articles 80-93 of the Cr. Pro. C. As per Article 80 of the Cr. Pro. C., the prosecution has this option for offences that fall within the jurisdiction of the High Court. Of these offences, the law requires the prosecution to order PI only for aggravated homicide and aggravated robbery unless the High Court exempts it from this

${ }^{18}$ However, no law obliges the prosecutor to prosecute an accused after a preliminary inquiry. Hence, the prosecutor at the High Court level may refuse to institute a criminal proceeding in accordance with Article 42(1)(a) of the Code when the prosecutor generally feels that he will have difficulty establishing the guilt of the accused. That would be the case if witnesses crucial to his case fared badly during cross examination at the preliminary inquiry or if witnesses called by the court testified persuasively in favor of the accused. The non-binding nature of the committal court's decision is clear from Article 109(2) of the Cr. Pro. C., which allows the prosecutor, where he believes it to be appropriate on the basis of the record of preliminary inquiry, to file a charge in a lower court "notwithstanding the decision of the committing court." Wondwossen Demissie Kassa (2012). Ethiopian Criminal Procedure Textbook, p. 265.

19 Stanley Z. Fisher (1969), Ethiopian Criminal Procedure: A Sourcebook (Addis Ababa: The Faculty of Law, Haile Sellassie I University), note 21, p. 200.

20 Jetu Edosa (2020), Analysis: Conducting Preliminary Inquiry in 'Jawar Mohammed et al. v. Ethiopia': Tactical or Technical Procedure? Addis standard, 7 August. < https://addisstandard.com/analysis/>. 
obligation. In all other cases, the public prosecution has a discretion to or not to order PI. ${ }^{21}$

Because PI, in other jurisdictions, is meant to protect the interest of the accused, the right of the accused to avoid this procedure is recognized. ${ }^{22}$ The Cr. Pro. C., by giving discretion to the prosecutor, denies the accused the right to waiver of this procedure. In the case referred in the introduction, the prosecution insisted that the PI be conducted. While this might not be incompatible with the $\mathrm{Cr}$. Pro. C, it departs not only from the practice in the past where the prosecution does not normally use the PI proceeding. It is also a departure from the generally recognized right of the accused to waiver of the procedure.

\section{Compatibility of the Preservation Function of PI with the Right to a Fair Trial}

The law of PI in Ethiopia lacks rational premises. This causes much concern because it has worrisome impact on the right of the accused to a fair trial. That is so for it compromises the principle of equality of arms and the right to confrontation, both of which are aspects of a fair trial.

\subsection{Principle of equality of arms}

Article 14(1) of the International Covenant on Civil and Political Rights (ICCPR), which forms an integral part of Ethiopian law, ${ }^{23}$ in part provides "all persons shall be equal before the courts" and that "in the determination of any criminal charge against him, ... everyone shall be entitled to a fair ... hearing." As per the UN Human Rights Committee, which provides authoritative meaning to the provisions of the ICCPR, the right to equality before courts ensures equality of arms. ${ }^{24}$ In Morael v. France, ${ }^{25}$ the Human Rights Committee observed that equality of arms is among the conditions

${ }^{21}$ Cr. Pro. C, Article 80. As per sub Article 1, the High Court is empowered to dispense the prosecution with the holding of the PI provided that the court is satisfied that the trial can be conducted "immediately."

${ }^{22}$ The only concern is to ensure that their decision that PI not be conducted is informed mainly consulting their lawyer.

${ }^{23}$ Article 9(4), FDRE Constitution

${ }^{24}$ UN Human Rights Committee (HRC), General comment no. 32, Article 14, Right to equality before courts and tribunals and to fair trial, 23 Aug. 2007, CCPR/C/GC/32, paragraph 13, available at:

https://www.refworld.org/docid/478b2b2f2.html [accessed 13 September 2020].

25 Yves Morael v. France, Communication No. 207/1986, U.N. Doc. Supp. No. 40 $(\mathrm{A} / 44 / 40)$ at $210(1989)$. 
that need to be satisfied for a trial to be compliant with one's right to a fair trial. In support of this link between fairness of trial and equality of arms, Professor Negri refers to equality of arms as the minimum threshold requirement for judicial processes to be considered fair, impartial and consistent with human right standards. ${ }^{26}$

This principle of equality of arms underpins the equal opportunities of the parties in criminal proceedings. It represents the "functional principle that participants in criminal proceedings must have equal opportunities to influence its course and outcome", and superiority of the prosecutor must be offset by "effective defense capabilities". ${ }^{27}$ By allowing the prosecution to introduce its evidence during the PI which could be used later during trial, without providing a similar opportunity to the accused, the PI seems to discriminate against the accused which would raise a fundamental question of fairness of the criminal proceeding.

The Human Right Committee's observation on this point is relevant. In its General Comment No 32 relating to Article 14 of the ICCPR, which provides for the right to a fair trial and in Lucy Dudko v. Australia, ${ }^{28}$ the Committee observes that "when a defendant is not given an opportunity equal to that of the State party in a hearing having relevance to the determination of a criminal charge, the principles of fairness and equality are engaged." According to the Committee, in such cases, "it is for the State party to show that any procedural inequality was based on reasonable and objective grounds, not entailing actual disadvantage or other unfairness to the defendant." 29

Because in other jurisdictions the purpose of PI is to evaluate the merit of the prosecution's case so that the accused shall not stand trial for nonmeritorious cases, the procedure, which appears to favour the prosecution,

${ }^{26}$ Stefania Negri (2007), 'Equality of Arms: Guiding Light or Empty Shell?’ In Michael Bohlander (ed), International Criminal Justice: A Critical Analysis of Institutions and Procedures, at 13.

${ }^{27}$ Krapac, D: Kazneno procesno pravo, Prva knjiga: Institucije, Narodne novine, V. izmijenjeno I dopun-jeno izdanje, Zagreb, 2012 cited in Marin Mrcela, Adversarial Principle, the Equality of Arms and Confrontational Right - European Court of Human Rights Recent Jurisprudence, EU and Comparative Law Issues and Challenges (2017), 15, 18.

${ }^{28}$ Communication No. 1347/2005, Dudko v. Australia, para. 7.4.

${ }^{29}$ UN Human Rights Committee (HRC), General omment no. 32, Article 14, Right to equality before courts and tribunals and to fair trial, 23 Aug.2007, CCPR/C/GC/32, $<$ https://www.refworld.org/docid/478b2b2f2.html>; Communication No. 1347/2005, Dudko v. Australia, para. 7.4. 
would not be considered to entail actual disadvantage or other unfairness to the accused. On the other hand, the PI under the Cr. Pro. C. does not serve the interest of the accused because it lacks its primary function of screening. It simply provides protection to the prosecution not to lose its evidence in case a witness is unavailable at the time of trial, without providing a similar treatment to the accused. By empowering the prosecution to decide whether or not PI is to be conducted and allowing the prosecution to make use of testimony given during the PI as evidence at the time of trial, the law clearly favours the prosecution.

Following the Human Right Committee's observation, this procedural inequality requires justification for it not to be considered as a violation of the principle of equality and one's right to a fair trial. For lack of the screening function, the law governing PI is fundamentally flawed and prejudicial to the accused making the procedural inequality hardly justifiable. As noted, the screening function of PI was omitted as a matter of expediency having no current relevance. Thus, other than pointing to the specific provisions of the $\mathrm{Cr}$. Pro. $\mathrm{C}$, one would not be able to explain the preferential treatment that the law provides to the prosecution as being based on reasonable and objective grounds with no impact on defence's capacity or other unfairness to the accused. In the absence of such explanation, provisions of PI, as incorporated under the Cr. Pro. C, would directly contradict with the guarantee of equality before courts recognized under Article 14 of the ICCPR.

\subsection{The Right to confrontation}

Both the FDRE Constitution ${ }^{30}$ and the $\mathrm{ICCPR}^{31}$ recognize the right of the accused to be confronted by the prosecution's witnesses. Article 144 of the Cr. Pro. C. authorizes putting in evidence depositions taken during PI where the witness is unavailable during the trial stage of a criminal proceeding for reasons specified thereunder. As noted, the OAG has expressed its intention to make use of this provision, if and when the need arises, in its argument for PI. The application of Article 144 would mean that the accused will not be able to access such witness at trial triggering the question of its compatibility with the right of the accused to confrontation.

${ }^{30}$ Article 20(4) of the FDRE Constitution recognizes the right of the accused "to full access to any evidence presented against them, to examine witnesses testifying against them ..."

${ }^{31}$ Article 14(3)(e) of the ICCPR, in part, provides "in the determination of any criminal charge against him [the accused], the accused has the right "to examine, or have examined, the witnesses against him." 
While the right to confrontation has been held to be "one of the fundamental guarantees of life and liberty," ${ }^{32}$ it is a right amenable to restriction. ${ }^{33}$ In other jurisdictions, making use of former testimony of a now unavailable witness when an opportunity for cross examination has been afforded $^{34}$ constitutes one of the exceptions where the accused will not be able to cross examine prosecution's witness during trial. Introducing depositions given during PI where the witness is not available at the time of trial falls within the exception that allows restriction of the right to confrontation. In these jurisdictions, its screening function makes the PI a judicial process serving the interest of the accused.

In addition to affording the accused the opportunity to cross examine witnesses of the prosecution, the PI in other jurisdictions empowers the court to decide whether the prosecution's case has merit to proceed for trial. That there is a possibility for dismissal of the prosecution's case would be an incentive for the accused to be actively engaged during the PI including by cross examining the prosecution's witness and showing that the prosecution does not have a case warranting trial. In view of this significant purpose of PI from the view point of the accused it is not likely for them not to exercise their right to confrontation during $\mathrm{PI} .{ }^{35}$

However, this logic would not work under the Cr. Pro. C. The difference between the PI in Ethiopia and in other jurisdictions, as discussed above, means the aptness of using the PI for perpetuating testimony in other jurisdictions does not warrant acceptance of the use of the PI for a similar purpose in Ethiopia.

True, as per the reading of Articles 88 and 147 of the Cr. Pro. $C,{ }^{36}$ the accused has the right to cross examine witnesses of the prosecution during PI. From this it seems to follow that introducing at one's trial a testimony given during PI would not be incompatible with one's right to confrontation as they are deemed to have had the opportunity, during the PI, to cross examine the witness. However, the matter is not as simple as that.

${ }^{32}$ Kirby v. United States, 174 U.S. 47, 55 (1898).

33 Robert G Sachse (1975), Preliminary Hearing and the Right to Confrontation: Disheroon v. State 10 Tulsa LJ 663, 664.

${ }^{34}$ Mattox v. United States, 156 U.S. 237 (1895).

${ }^{35}$ If, under such circumstances, they did not cross examine witnesses of the prosecution it would be reasonable to see it as a case of waiver.

${ }^{36}$ Article 88 dealing with recording of evidence provides that eevidence be recorded in accordance with Art. 147. Article 147 (3) states "the evidence shall be divided into evidence-in-chief, cross-examination and re-examination with a note as to where the cross-examination and re-examination begin and end." 
First, strictly speaking legal instruments that recognize confrontation as a right (including Article 20/4 of the FDRE Constitution) recognize it as a trial right. In Ethiopia, unlike in other jurisdictions, the committal court does not have the power to terminate the case even where the prosecution does not have evidence to warrant prosecution. In terms of function, PI is closer to investigation than to a judicial process, which makes it not to be capable of providing a function equivalent to trial in offering genuine opportunity to exercise right to confrontation.

Second, that the PI does not offer its primary function of screening means accused persons do not have the incentive to diligently participate in the proceeding. The defence would prefer not to reveal their criminal defence strategy to cross examining the prosecution's witness for nothing. This makes the PI not to be considered to offer the accused a meaningful opportunity to cross examine. ${ }^{37}$

Third, as noted above, the law regulating PI is incompatible with principle of equality of arms rendering its constitutionality dubious. While the right to confrontation can be subject to limitation such as when the accused has a genuine opportunity to exercise the right at the time of PI, it should not be restricted by a skewed procedure which is incompatible with principle of equality of arms.

\section{Concluding Remarks}

While the OAG's position regarding its discretion to order PI and the purpose the PI is meant to serve might be consistent with the provisions of the Cr. Pro C., it loses sight of the impact of applying these provisions on the right of the accused to a fair trial. As noted, the PI incorporated under the Cr. Pro. C. does not serve the primary purpose of a PI, i.e. - screening. By simply allowing the prosecution to get its evidence preserved for later use, without providing a similar opportunity to the accused, provisions of the $\mathrm{Cr}$. Pro. C. governing PI discriminate against the accused in violation of the principle of equality of arms. Furthermore, by authorizing the prosecution to introduce at trial depositions taken during the PI, the Cr. Pro. C. compromises one's right to confrontation.

To the extent the application of the law regulating PI infringes these rights, it would be incompatible with the right to a fair trial recognized under Article 14 of the ICCPR. Where there is a discrepancy between domestic

\footnotetext{
${ }^{37}$ Not cross-examining prosecution's witness is a rational decision from which adverse inference against the accused should not be made.
} 
law and provisions of the ICCPR, the Human Rights Committee, in its General Comment No. 32, has noted that domestic laws should yield to guarantees of fair trial under Article 14, which embraces the principle of equality of arms and the right to confrontation. Relatedly, as per Article 27 of the 1969 Vienna Convention on the Law of Treaties domestic laws cannot be justifications for not complying with treaty obligations.

Furthermore, as per Article 2(1) of the ICCPR, Ethiopia has undertaken to respect and ensure the enforcement of the rights recognized in the Covenant including the right to a fair trial. Where there is incompatibility between domestic laws and the provisions of the ICCPR, Article 2(2) of the latter requires state parties to take measures as may be necessary to give effect to the rights recognized in the Covenant.

A new Criminal Procedure and Evidence Code is in its final stage of drafting. The lawmaker has to make use of this opportunity to consider including the screening function of PI and address the concerns raised above. Pending the draft Code, it is proposed that the OAG seeks permission from the High Court that trial be conducted without PI in cases of aggravated homicide and aggravated robbery; and, in all other cases, employ its discretion to avoid PI.

Where, and if, the OAG orders PI, as it did in the case of opposition political party leaders, the trial court may have to consider declaring testimony obtained through PI as inadmissible evidence or refer the matter to the Council of Constitutional Inquiry for constitutional interpretation. By so doing the three organs of government would be discharging their respective constitutionally mandated responsibilities in enforcing and respecting the right of the accused. 